\title{
An integrated control on thermal and noise environment of tropical building material
}

\author{
FX Teddy Badai Samodra ${ }^{1, *}$, Irvansyah ${ }^{1}$, Collinthia Erwindi $^{1}$ \\ ${ }^{1}$ Department of Architecture, Institut Teknologi Sepuluh Nopember, Kampus ITS Sukolilo, Surabaya 60111, Indonesia
}

\begin{abstract}
The environmental problems of thermal and noise environment are recently considered the most important contributors to the tropical building in an urban area. The porous tropical materials provide both a solution for cooling and airborne noise problem from the source to receiver when the wind is in the same direction. This research optimizes the integrated control of thermal and noise environment which are directed into building material evaluation. Surabaya is selected as representative of the hotter area of the lowland while Malang is determined as the colder urban area of the highland. An eco-tropical lightweight material, wood, is examined as a case study. The field measurement for surface material temperature and its transmission loss were conducted in order to give information on thermal and acoustical properties of the material. The optimization is conducted by comparing Sound Reduction Index and by Conduction Heat Flow. The results highlighted that for the same material, the thickness that effect on its mass is important for both thermal and noise control. The higher the thickness is, the higher the Sound Reduction Index and the lower the conduction heat flow are. Modifying material by adding the thickness of wood results that by material mass minimum $36.5 \mathrm{~kg} / \mathrm{m}^{2}$, the critical lowland building meets the standard of World Health Organization noise limits and has lower heat gain.
\end{abstract}

\section{Introduction}

The building in the urban area generates the environmental difficulties of thermal and noise environment as the most serious factors. In general, the tropical problem is indicated by relatively high environmental temperatures and its air humidity. Cities, however, have inadequate space for accelerating air movement because of the high compactness of buildings but they optimize themselves as a barrier for noise propagation from urban traffic. This analysis can be attached to allow sustainable site planning of highdensity environments, both building and human activities, for improvement of both thermal and noise environments. However, the requirements for integrated factors for controlling thermal and noise related to material were not found in the previous results. Most of them proposed many factors separately [1-4].

In tropical regions, the traditional building was designed in rural terrain roughness because of the low building density. Recently, these types have been constructed in several places, such as urban and city areas. Those conditions have significances on a design of the surroundings and material performances. The porous walls provide a solution for cooling, however, can allow airborne noise transmission from the source to the receiver once the wind is in the same direction. In addition to Samodra, 2017 [5] related to thermoacoustics control by Window to Wall Ratio, this research optimizes integrated control for thermal and noise environment which are directed into building material optimization.

\section{Research Method}

Tropical traditional buildings have climate as form modifier; actually, the building was more indicated by social and cultural characteristics. On the other hand, the technique for controlling both the thermal environment and the noise has been passed down through generations. Certainly, it has been conducted with enhancements made from one generation to the next. This study examines tropical traditional material of wall as both the thermal and noise barriers (U-value $=3.19 \mathrm{~W} / \mathrm{m}^{2} \mathrm{~K}$, Tlag $=0.3$ hours $)$ and acoustical properties: wood $\left(\mathrm{TL}_{\text {wood in }}\right.$ average frequency is $18 \mathrm{~dB}$ while $21 \mathrm{~dB}$ is for $1000 \mathrm{~Hz}$ ). The tropical typical locations are Surabaya $\left(7.2^{\circ} \mathrm{S}, 112^{\circ} \mathrm{E}, 3\right.$ $\mathrm{m}$ above mean sea level) as the lowland area and Malang $\left(7.8^{\circ} \mathrm{S}, 112^{\circ} \mathrm{E}, 575 \mathrm{~m}\right.$ above mean sea level) as the highland area because of the obtainability of the existence building in the major city in Java Island. The field study was undertaken to classify and to evaluate the real conditions of a building envelope surface by field measurements and as input for scientific optimization.

Figure 1 presents the profile of a building envelope in detail. The orientation rule was set with $0^{\circ}$ as the Southern orientation and applied counter-clockwise. The traditional Javanese buildings in both lowland and highland areas were assessed with the identical object as thermal and noise evaluation. All materials used by a

* Corresponding author: fxteddybs@arch.its.ac.id 
traditional building were recognized as lightweight materials. The study object was measured in all building envelope elements of the indoor and outdoor areas to compare the levels of the thermal comfort. The lowland and highland buildings were measured using the same approaches for the location, tools, and time. This field measurement study was taken as the minimum influence from rainfall, which was planned to evaluate the real building performance.

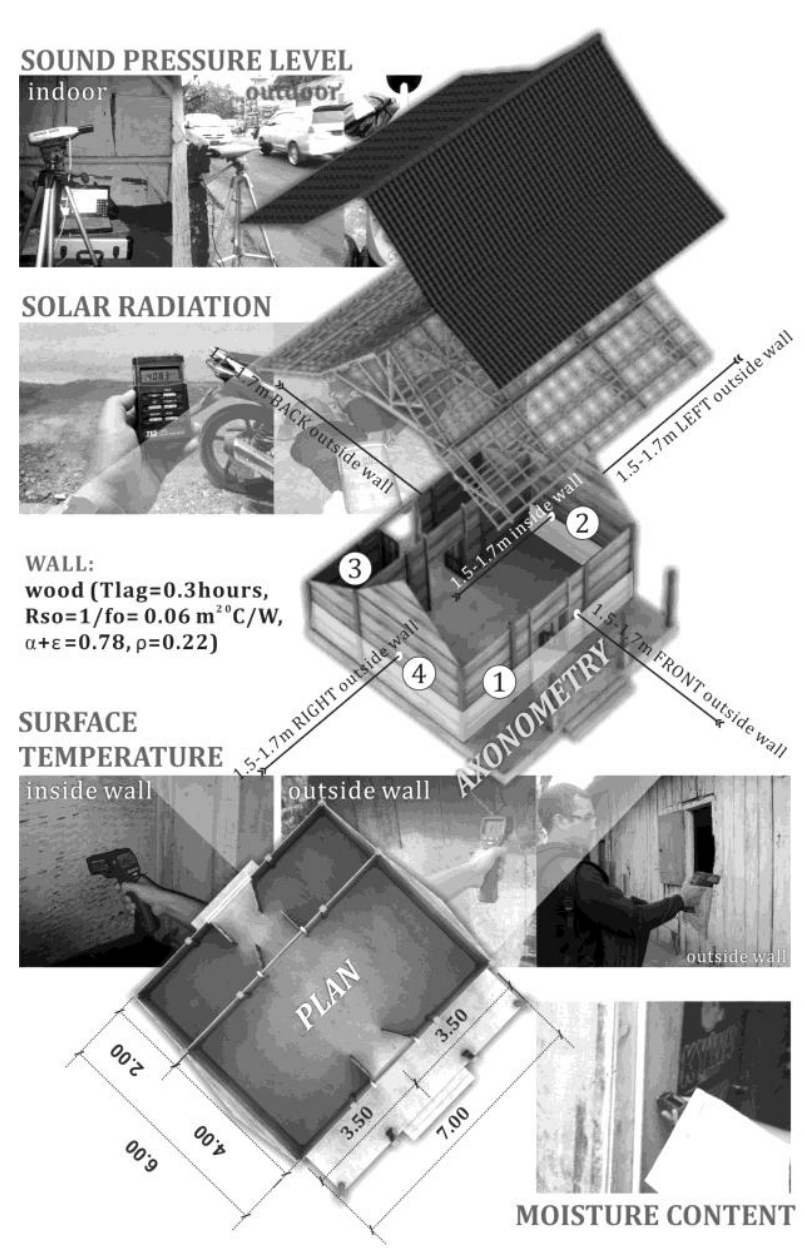

Fig. 1. Object measurement of surface material temperature.

For the surface temperature measurement, an infrared or no-touch thermometer was selected to use with an additional checked moisture content of the material using a moisture meter and surroundings solar radiation with a solar power meter (Figure 1 and Table 1). Each manual measurement was conducted for approximately 3-5 minutes to obtain a steady value for every instrument because the condition can change definitely. The data collections have a sensitive instrument sensor with the free disturbance on its height location for 1.5-1.7 $\mathrm{m}$ of height for both outside and inside walls. At the same location, height and time, three times per day completed the same period, 7 days a week are a representation of the inhabitant lifestyle. With the same object setting to thermal observation, the noise measurement using sound level meter was directed to tropical traditional houses in both lowland and highland areas for noise source place and the occupant or all sides of receiver noise location.
The optimization of thermal and noise control is examined using formulation Sound Reduction Index (SRI) of wall material and material Conduction Heat Flow Rate for noise and thermal, respectively. All are integrated to reach WHO standard [6], field study grades are taken from Samodra (2018) [7], and recommended by Indonesian Standard [8].

Table 1. Field measurement setting.

\begin{tabular}{|c|c|c|c|}
\hline Tools & Specification & Location & Time \\
\hline $\begin{array}{l}\text { Infra-red } \\
\text { Thermo- } \\
\text { meter for } \\
\text { Surface } \\
\text { tempera- } \\
\text { ture }\end{array}$ & $\begin{array}{l}\text { Range: - } \\
20^{\circ} \mathrm{C} \sim 537^{\circ} \mathrm{C} \\
\text { Emissivity: } \\
0.95 \\
\text { Field of view: } \\
12: 1 \\
\text { Resolution: } \\
0.1^{\circ} \mathrm{C}\end{array}$ & \multirow[t]{2}{*}{$\begin{array}{l}1.5-1.7 \mathrm{~m} \text { of } \\
\text { reference height } \\
\text { for Out-Inside } \\
\text { Walls }\end{array}$} & \multirow{4}{*}{$\begin{array}{l}7 \text { days and } \\
3 \text { times a } \\
\text { Day: } \\
\text { Morning } \\
(06: 00- \\
08: 00) \text {, } \\
\text { Afternoon } \\
(12: 00- \\
14: 00) \text {, } \\
\text { Evening } \\
(17: 00- \\
19: 00)\end{array}$} \\
\hline $\begin{array}{l}\text { Moisture } \\
\text { Meter for } \\
\text { Moisture } \\
\text { Content }\end{array}$ & $\begin{array}{l}\text { Range: } 0 \% \text { to } \\
90 \% \text {. } \\
\text { Accuracy: } \\
\pm 0.1 \%\end{array}$ & & \\
\hline $\begin{array}{l}\text { Solar } \\
\text { Power } \\
\text { Meter for } \\
\text { Solar } \\
\text { Radiation }\end{array}$ & $\begin{array}{l}\text { Range: } \\
0-2000 \mathrm{~W} / \mathrm{m}^{2} \text {; } \\
\text { Accuracy: } \\
\pm 10 \mathrm{~W} / \mathrm{m}^{2}\end{array}$ & $\begin{array}{l}\text { Ground } \\
\text { landscape and } \\
\text { hardscape }\end{array}$ & \\
\hline $\begin{array}{l}\text { Sound } \\
\text { Level } \\
\text { Meter for } \\
\text { Sound } \\
\text { Pressure } \\
\text { Level }\end{array}$ & $\begin{array}{l}\text { - Weighting: } \\
\text { A } \\
\text { - Single } \\
\text { dynamic } \\
\text { range: } 30-137 \\
\text { dB(A) in class } \\
1 \text { and class } 2\end{array}$ & $\begin{array}{l}\text { Road or Noise } \\
\text { Source and } \\
\text { Indoor (Terrace, } \\
\text { Front-Back- } \\
\text { Right-Left } \\
\text { sides: } 0.6 \mathrm{~m} \text { to } \\
1.5 \mathrm{~m} \text { of height } \\
\text { (sitting/standing } \\
\text { reference) }\end{array}$ & \\
\hline
\end{tabular}

\section{Results and Discussion}

\subsection{Field Observation}

In general, the surface temperature has linear dealings with solar radiation at ground level, a higher temperature of the sheltered surface or low exposed area may potential be interrupted by an air movement. Figure 2 shows the significant difference between exposedsheltered and lowland-highland, even though they are in the low solar radiation when cloudy sky situation. It may be directed by accumulative actions of the inhabitants and their neighbors.

In tropical climates, humidity fluctuated from lowland and highland more than the other climatic elements. Moreover, two seasons of Indonesia, rainy and dry, give a significant effect to the high relative humidity and its moisture content in building envelope in addition to the sky clearness. Because the location is near to a water source like toilet or bathroom, this study finds that the exposed East wall as the highest moisture content, that is frequently used in the afternoon (Figure 3). In general, the typical lowland building has better material performance in controlling the environment by 
decreasing the extreme condition compared to the highland.

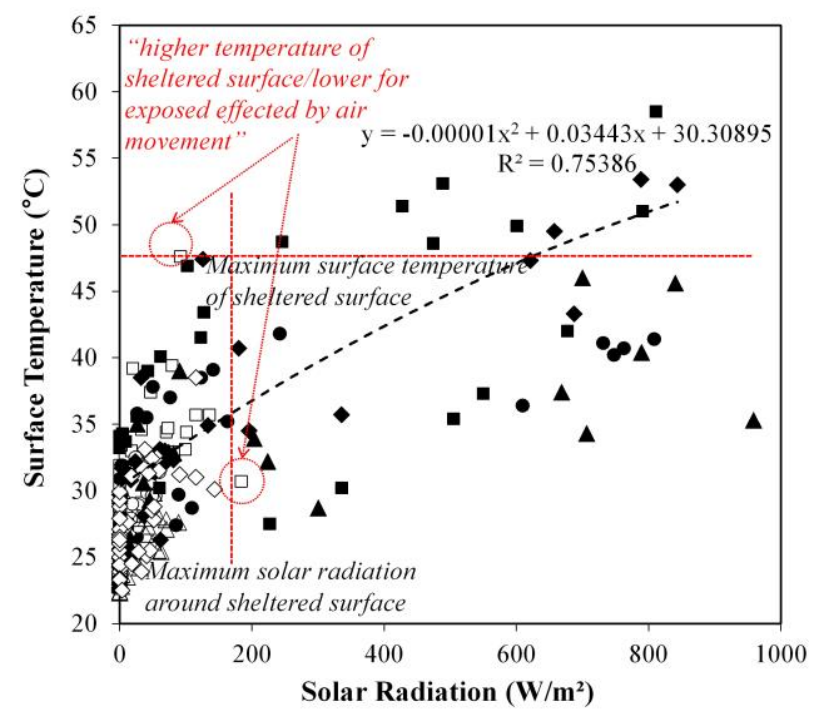

- LOWLAND/Exposed Softscape O LOWLAND/Sheltered Softscape - LOWLAND/Exposed Hardscape $\square$ LOWLAND/Sheltered Hardscape \ HIGHLAND/Exposed Softscape $\triangle$ HIGHLAND/Sheltered Softscape - HIGHLAND/Exposed Hardscape $\diamond$ HIGHLAND/Sheltered Hardscape

Fig.2. Effect solar radiation on surface material temperature.

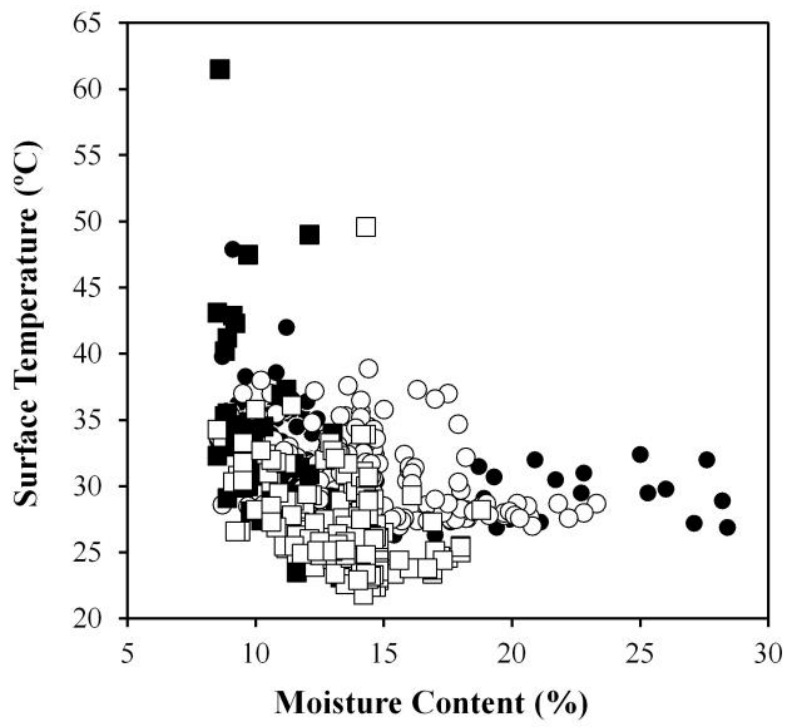

$\begin{array}{ll}\bullet \text { LOWLAND/Exposed Wall } & \text { OLOWLAND/Sheltered Wall } \\ \text { - HIGHLAND/Exposed Wall } & \square \text { HIGHLAND/Sheltered Wall }\end{array}$

Fig. 3. Moisture content and surface material temperature relationships of walls.

The noise propagation has various attenuation factors such as air absorption, barrier diffraction, and its ground reflectance [9]. Those factors have significance aside from the noise level of the source and the distance to a receiver as the main issues. Moreover, the receiver location, the environment setting such as urban, suburban, rural terrain and the accessible space for site barrier are also the significant factors [10].
By distance and the wall material made from wood or bamboo, with the traffic as the main source, sound pressure level is controlled up to $20 \mathrm{~dB}$ and $15 \mathrm{~dB}$ for lowland and for highland, respectively. Though traditional wall has low composite transmission loss, it decreases insufficient rate. By $12 \mathrm{~m}$ distance and building as a barrier, the noise attenuation is up to 8 $\mathrm{dBA}$. In receiving noise, the role of the building orientations is the capability of determining the zoning (Figure 4). It is caused by the closed distance of the receiver from the source and the contribution of the building barrier itself.

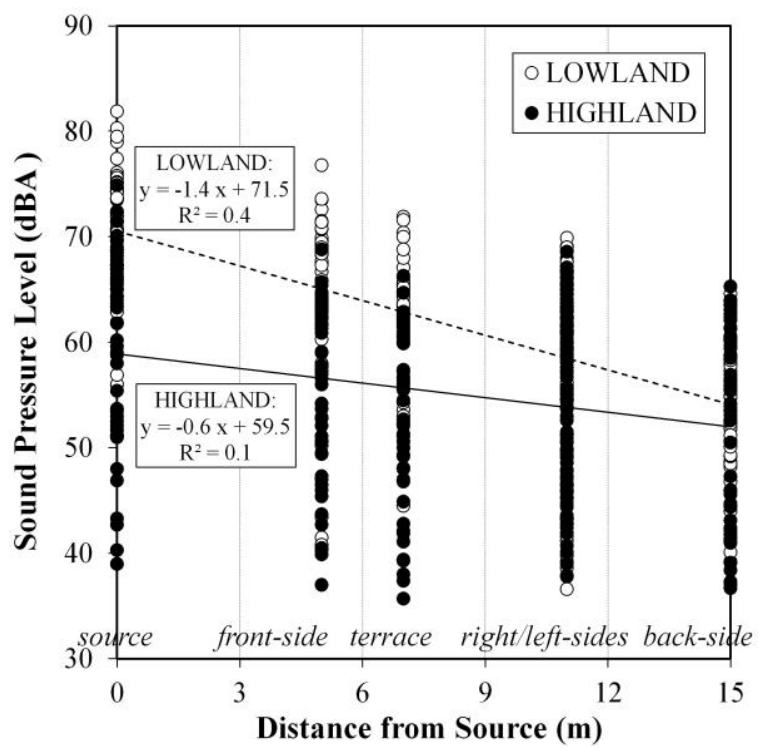

Fig. 4. Distance and material effects on noise propagation.

The requirements for thermal comfort is the primary reason associated with the others. Meanwhile, because noise control is frequently placed as a low urgency plan until an emergency condition ascends $[11,12]$. However, by this study, both thermal and noise are discussed as significant factors that can be examined simultaneously for existing building using calculation technique.

Based on analysis of prevailing material properties, the analysis of dealing the heat and noise reduction can be briefly noted as follows: The low time lag with high transmittance, wood has a chance in resulting similar outdoor and indoor temperature. In about thin layer of $0.01 \mathrm{~m}$ thickness only, the wood wall has a capability of insulating the heat from the environment depending on its temperature. With lightweight properties ( $\mathrm{W}$ is 3.6 $\mathrm{kg} / \mathrm{m}^{2}$ ), the wood has a substantially good performance from the parameter that the data plotted less than 32 deficiencies and its extreme deficiency at any given frequency does not exceed 8 decibels. For an example in $1000 \mathrm{~Hz}$, it results in a TL. $21 \mathrm{dBA}$ and the wood has an STC21. It indicates a good in a single number rating of the material effectiveness to retard the airborne sound that is frequently affected by environmental noise.

For shading efficiency, the prevailing building is deliberated decent for decreasing surface temperature. The back wall or the South wall has the same surface temperatures with the air temperature on all the days because building covers are continuously shaded. 
Actually, it has no effect on noise attenuation. Meanwhile, building envelope slope is good for eliminating solar irradiance and surface temperature effects even no significant effect on noise control. Nevertheless, this still has an impact to generate diffraction influence on noise propagation.

In terms of building aperture in the surviving building, the opening as aperture can be divided into opened and closed settings. In case of material performance assessment, the closed schedule for both in thermal and noise environment is set up. As a note that, the existing has the limited opening, they have porous envelopes because their preferred living is in the outdoor). With TLwood in $1000 \mathrm{~Hz}$, the closed aperture still has a capability to control the noise exposure in all places and time for both reaching the Indonesian and WHO Standards.

\subsection{Integrating thermal comfort with noise propagation}

The existing noise propagation generates an effective noise attenuation by its tropical material, for both lowland and highland (Figure 5 and Figure 6). With TL18 dBA, actually, the wood has a capability of reducing noise annoyance. However, it does not ensure the achievement for all standards. Based on Equation 1 [13], noise experiment by the wall material Sound Reduction Index or Transmission loss is used as the basis of integration on improvement. It shows that by prevailing tropical material (noted: wood, $24.8 \mathrm{~kg} / \mathrm{m}^{2}$, thickness $30 \mathrm{~mm}$ ) for all frequency condition $(20 \mathrm{~Hz}-20$ $\mathrm{kHz}$ ), location, and time, it meets to the Indonesia Standard and field study noise restrictions (Figure 7 and Figure 8). However, in the lowland night-time, the lowest frequency $(20 \mathrm{~Hz})$ does not comply to WHO Standard (the value is more than $30 \mathrm{dBA}$ ). Therefore, the material modification by adding the thickness is the easiest strategy.

$$
\mathrm{SRIW}_{\mathrm{A}}=-10 \log \left[\frac{\mathrm{Aw} \cdot 10^{\left(\frac{-\mathrm{SRI}}{10}\right)}+\mathrm{A}_{\mathrm{A}} \cdot 10^{\left(\frac{-\mathrm{SRIA}_{\mathrm{A}}}{10}\right)}}{\left(\mathrm{Aw}_{\mathrm{w}}+\mathrm{A}_{\mathrm{A}}\right)}\right]
$$

Where $\mathrm{SRI}_{\mathrm{W}+\mathrm{A}} / \mathrm{SRI} / \mathrm{SRI}_{\mathrm{A}}$ - Sound Reduction Index of composite panel / Wall / Aperture [dB];

$\mathrm{A}_{\mathrm{W}} / \mathrm{A}_{\mathrm{A}}$ - Wall Area / Aperture Area $\left[\mathrm{m}^{2}\right]$;

A - Area $\left(\mathrm{m}^{2}\right)$;

Qc - Conduction Heat Flow (W)

$\mathrm{U}$ - Thermal Transmittance $\left(\mathrm{W} / \mathrm{m}^{2} \mathrm{~K}\right)$;

$\Delta \mathrm{T}$ - Temperature Difference $\left({ }^{\circ} \mathrm{C}\right)$

Simulation of modifying the thickness of the existing wood results that by material mass at minimum 36.5 $\mathrm{kg} / \mathrm{m}^{2}$ or the thickness is $44.2 \mathrm{~mm}$, the lowland building meets with the standard of WHO noise parameter even for the night-time (Figure 9). Meanwhile, changing the material scheme by totally substituting the wood to a brick as a common material in Indonesia, the lowest frequency, $20 \mathrm{~Hz}$, catches $28.66 \mathrm{dBA}$ and it complies to WHO Standard (note: opened aperture, $\mathrm{SRI}_{\mathrm{W}}=0$ ).

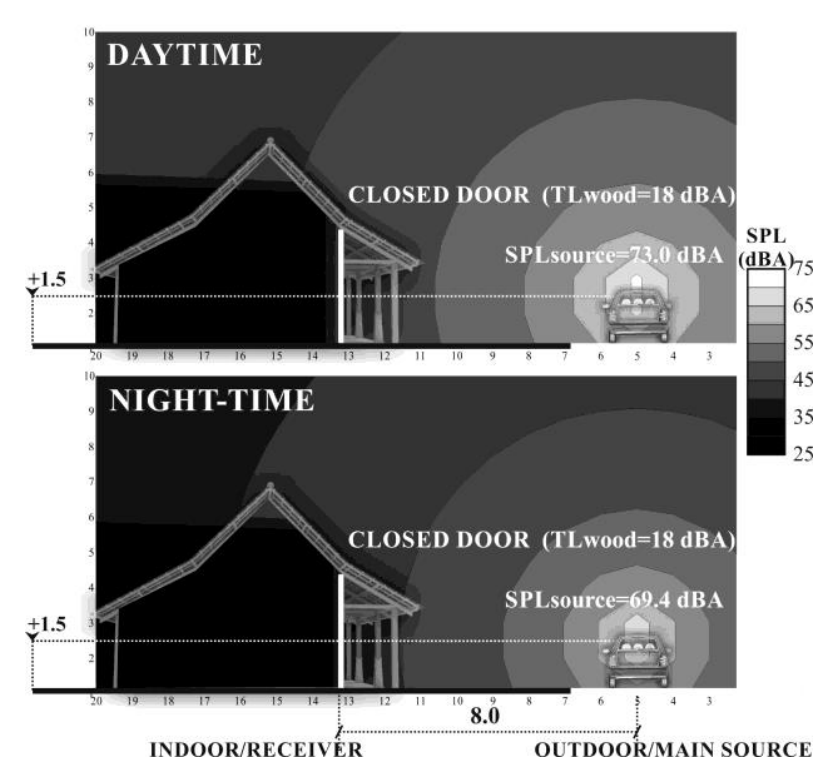

Fig. 5. Matlab simulation on the closed door of existing lowland building.

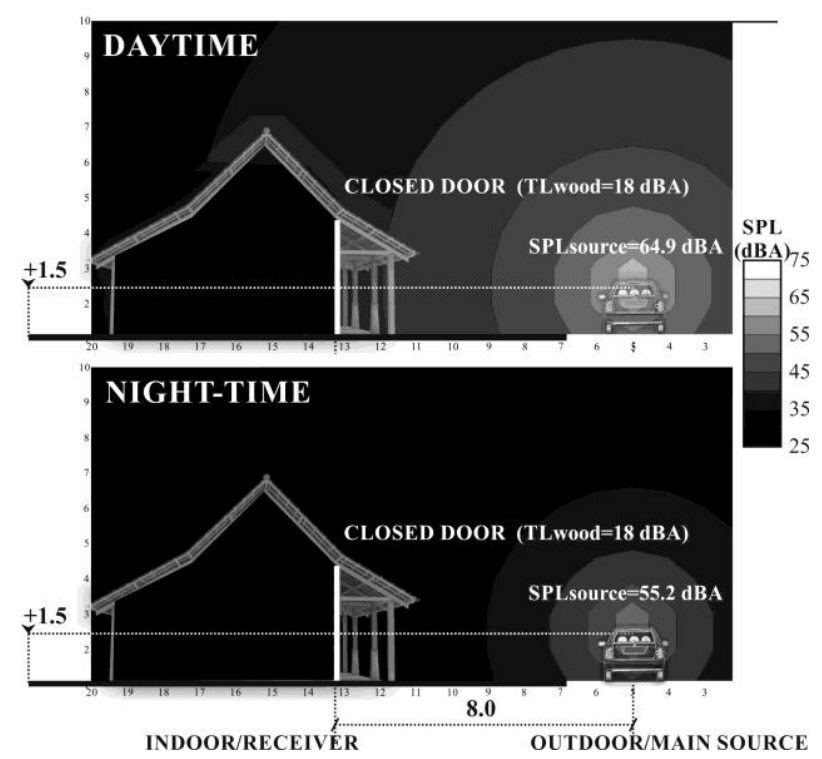

Fig. 6. Matlab simulation on the closed door of existing highland building.

For combined design, accomplish to preceding research [7], the enhancement for thermal environment assumes the SRI of noise environment by means of conduction heat flow examination. Thermal simulation evaluates the material Conduction Heat Flow Rate calculation (Equation 2). Meanwhile, the temperature change applies the upper and lower limits of field study standard $\left(28.60-30.00^{\circ} \mathrm{C}\right.$ and $28.55-30.05^{\circ} \mathrm{C}$ for lowland and highland, respectively). It is also compared by the outdoor temperature (maximum and minimum). 


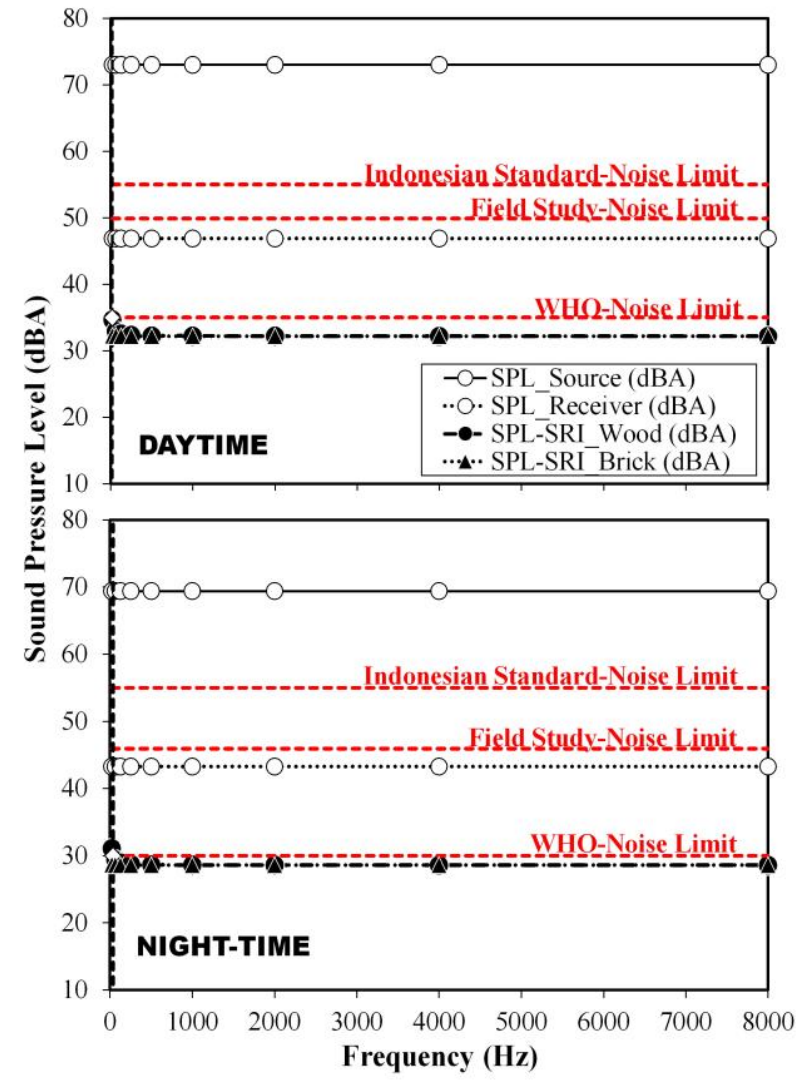

Fig. 7. Lowland noise simulation by Sound Reduction Index existing material and brick walls.

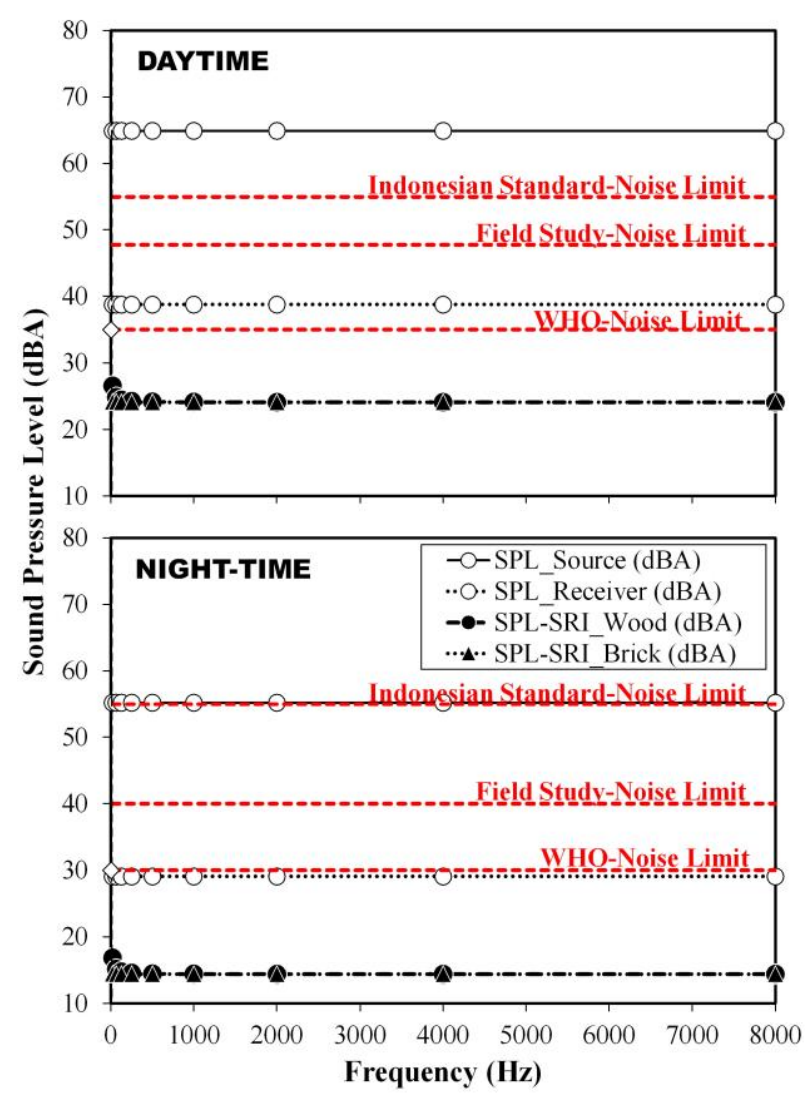

Fig. 8. Highland noise simulation by Sound Reduction Index existing material and brick walls.

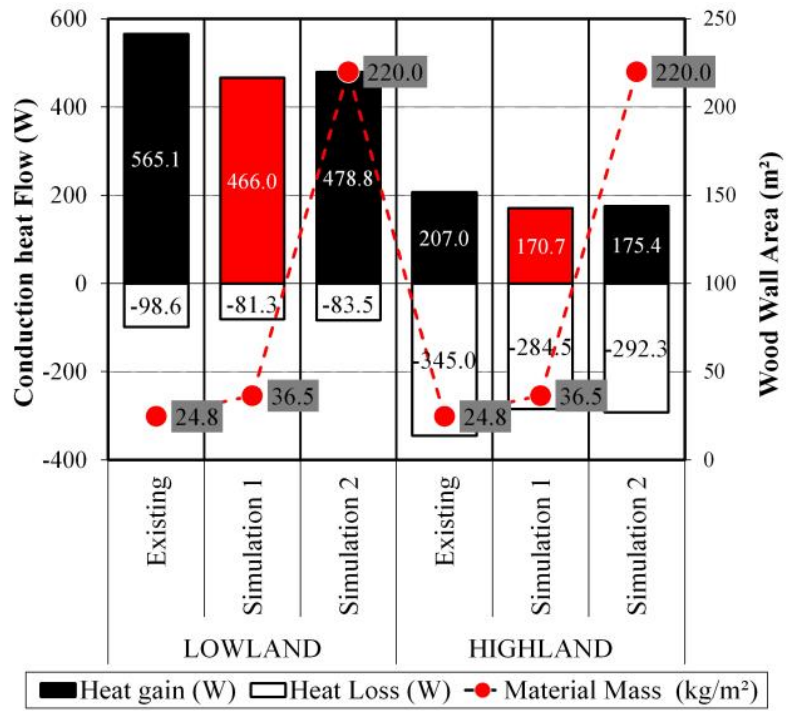

Simulation 1: Modified Experiment for Wood Mass by Changing wall thickness from $30 \mathrm{~mm}$ in existing to $44.2 \mathrm{~mm}$ $\left(36.5 \mathrm{~kg} / \mathrm{m}^{2}\right)$ as a minimum requirement for noise control.

Simulation 2: Material Change Experiment by Brick Wall (110 $\mathrm{mm}, 220 \mathrm{~kg} / \mathrm{m}^{2}$ )

Fig. 9. Thermal simulation.

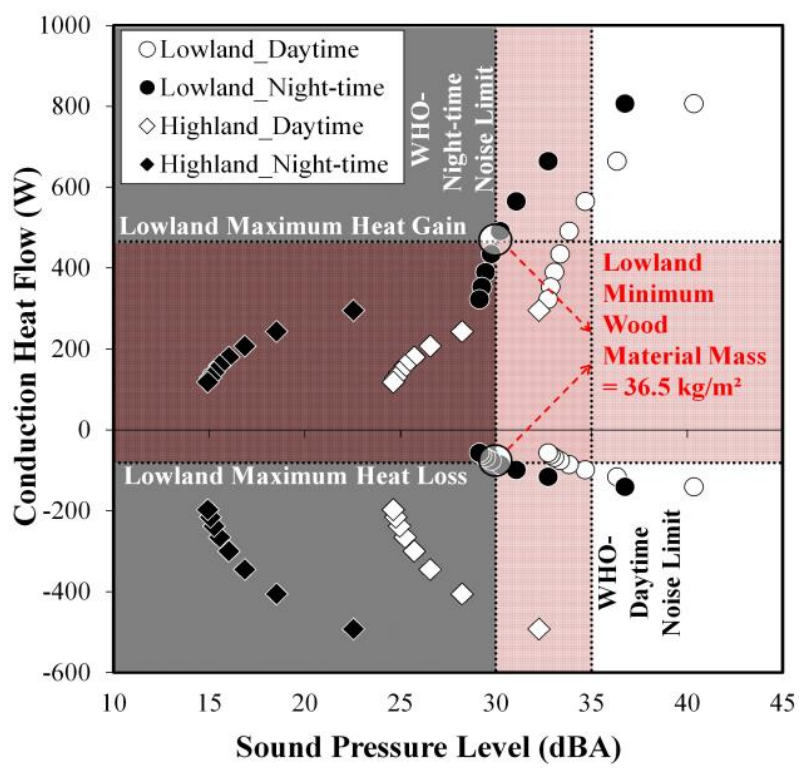

Figure 10. Dealing conduction heat flow with noise control.

By simulating on a material as proposed by noise modification, the Simulation 1 where wood Wall is 36.5 $\mathrm{kg} / \mathrm{m}^{2}$ and thickness $44.2 \mathrm{~mm}$, it has better performance than both the prevailing model and brick wall (Figure 9). The high and thick material as brick wall $\left(220 \mathrm{~kg} / \mathrm{m}^{2}\right.$, $110 \mathrm{~mm}$ ), it has a little worse result compared to the modified wood. It has higher conductivity $(\mathrm{W} / \mathrm{mK})$ than wood has $(0.711$ compared to $0.209 \mathrm{~W} / \mathrm{m} \mathrm{K})$.

As shown in Figure 10, an integrated evaluation on conduction heat flow and noise attenuation mechanism for different material, in addition to thickness, conductivity has an impact on a thermal transmittance of material (Uvalue material). However, for no different material, the thickness that effects on material mass is 
significant for both controlling thermal and noise and when the thickness is high the higher SRI and lower Qc are obtained. With this results, the typical tropical building material adapts to the most critical urban factor, heat and noise, in the today's condition of the public spatial environment.

\section{Conclusion}

In the optimization of integrated examination by controlling the conduction heat flow and noise for different material, the thickness modification generates the material conductivity to effect the thermal transmittance. However, the same material thickness that effects on its mass is important for both thermal and noise control. The higher the thickness is, the higher the SRI and the lower the Qc are. If the simulation conducting by modifying the material thickness of wood results with material mass minimum $36.5 \mathrm{~kg} / \mathrm{m}^{2}$, the thickness is $44.2 \mathrm{~mm}$, the lowland building complies the requirement of the standard of WHO noise limits and has low both heat gain and heat loss.

In general, because of the ecological and energy efficiency reasons, the local material from the tropical traditional building has been adopted for common living space of the tropical modern building in an urban area. However, the adaption building material to the variation of the environment and its orientation has not been found in the previous studies [1, 14-17]. Therefore, by this research, the results are expected to reinvigorate local material in adapting to the changed environment for today's building.

For future works, the combination site barrier and building envelope materials evaluation to deal thermal and noise control could be a novel idea. Building material industry should consider how to produce sustainable material properties for urban development as generated and proposed by this research.

This research is part of Excellent Primary Research of Higher Education, Penelitian Dasar Unggulan Perguruan Tinggi No. $882 / \mathrm{PKS} / \mathrm{ITS} / 2018$. The authors gratefully acknowledge this financial and technical support.

\section{References}

1. D.J.C. Hii, C.K. Heng, L.C. Malone-Lee, J. Zhang, N. Ibrahim, Y.C. Huang, P. Janssen, Proceedings of Building Simulation, 12 (IBPSA Sydney, 2011)

2. L. Huang, Y, Zhu, Q. Ouyang, B. Cao, Building and Environment, 49 (2012)

3. M. Hodgson, A. Alireza Khaleghi, Building Acoustics, 19 (2012)

4. M. Caniato, F. Bettarello, A. Ferluga, L. Marsich, C. Schmid, P. Fausti, Building Acoustics 24, 4 (2017)

5. F.X.T.B., Samodra, Journal of Architecture and Urbanism 41, 4 (2017)

6. B. Berglund, T. Lindvall, D. Schwela, K.T. Goh, Guidelines for community noise (World Health Organization, 2000)
7. F.X.T.B., Samodra, IOP Conf. Ser.: Earth Environ. Sci., 126 (2018)

8. Minister for The Environment Decree, Republic of Indonesia, No. 48/MENLH/11/1996. Noise Level Standard

9. S. Sakamoto, Acoust. Sci. \& Tech. 36, 2 (2015)

10. T.V. Renterghem, J. Forssen, K. Attenborough, P. Jean, J. Defrance, M. Hornikx, J. Kang, Applied Acoustics, 92 (2015)

11. P.O. Fanger, Thermal comfort: Analysis and applications in environmental engineering. (Danish Technical Press, Copenhagen, 1970)

12. J.P. Cowan, Handbook of environmental acoustics (John Wiley \& Sons, Inc., Canada, 1994)

13. M.H.F. De Salis, D.J. Oldham, S. Sharples, Building and Environment, 37 (2002)

14. I.R. Maestre, J.L.F. Blázquez, F.J.G. Gallero, P.R. Cubillas, Energy and Buildings 101 (2015)

15. G. Vox, I. Blanco, E. Schettini, Building and Environment 129 (2018)

16. E.E. Alders, Architectural Science Review, 60 (2017)

17. F.X.T.B., Samodra, International Journal of Technology, 9 (2018) 